\title{
APPLYING IMPORTANT-PERFORMANCE ANALYSIS To Home Stay Service Performance
}

\author{
Han-Chen Huang \\ Department of Tourism and M.I.C.E., Chung Hua University, \\ 30012 Hsinchu, Taiwan.
}

\begin{abstract}
In 2019, Taiwan has more than 8,000 home stays, and competition is very intense. In addition to accommodation, catering, and other core services, home stay operators add many unique services to attract consumers, but not every service receives consumer's recognition. Therefore, through literature review, field survey, interviews with the home stay operators, and consumer survey, this research analyzes service performance by paired-samples t test and Important-Performance Analysis, and the research results can be used as a reference for home stay operators to improve their operational performance, in order to make their servicesmeet the needs of consumers.
\end{abstract}

\section{KEYWORDS}

Home Stay, Core services, Service Performance, Important-Performance Analysis

\section{INTRODUCTION}

In 2001, Taiwan began to implement the Two-day Weekend, and the quantity of domestic tourism reached 97.45 million in that year, and increased to more than 183.449 million [1] by 2017. In this context, there have been larger demands for tourist lodging. Therefore, Taiwan's government allows people to use their own residence in specific areas to apply for running home stays. As of March 2019, there have been 8,705 legitimate home stays in Taiwan (Table 1). Under such intense competition, many home stays have developed special services different from others to attract consumers; however, there are many examples of business failures. The main reason for business failure is that the services provided do not meet the requirements of the consumer $[2,3]$, which shows that operators should focus on self-righteous business practices and understand actual consumer demands. They should provide services that meet and even exceed the expectations of consumers, in order to win consumer loyalty in the fiercely competitive environment.

Table1. March, 2019 Monthly Report of Home Stay Facilities in Taiwan [4]

\begin{tabular}{|l|lc|l|}
\hline County / City & $\begin{array}{l}\text { No. of Home Stay } \\
\text { Facilities }\end{array}$ & No. of Rooms \\
\hline New Taipei City & 246 & 836 \\
\hline Taipei City & 1 & 5 \\
\hline Taoyuan County & 51 & 217 \\
\hline
\end{tabular}

DOI: $10.5121 /$ ijcsit.2019.11406 
International Journal of Computer Science \& Information Technology (IJCSIT) Vol 11, No 4, August 2019

\begin{tabular}{|l|l|l|}
\hline County / City & $\begin{array}{l}\text { No. of Home Stay } \\
\text { Facilities }\end{array}$ & No. of Rooms \\
\hline Taichung City & 93 & 352 \\
\hline Tainan City & 295 & 1066 \\
\hline Kaohsiung City & 69 & 280 \\
\hline Yilan County & 1447 & 5598 \\
\hline Hsinchu County & 82 & 382 \\
\hline Miaoli County & 308 & 1105 \\
\hline Changhua County & 62 & 256 \\
\hline Nantou County & 679 & 3324 \\
\hline Yunlin County & 67 & 300 \\
\hline Chiayi County & 204 & 718 \\
\hline Pingtung County & 783 & 3381 \\
\hline Taitung County & 1266 & 5529 \\
\hline Hualien County & 1829 & 7195 \\
\hline Penghu County & 719 & 3380 \\
\hline Keelung City & 1 & 5 \\
\hline Hsinchu City & 0 & 0 \\
\hline Chiayi City & 1 & 6 \\
\hline Kinmen County & 345 & 1672 \\
\hline Lienchiang County & 157 & 688 \\
\hline Total & 8705 & 36295 \\
\hline
\end{tabular}

The process of serving consumers may result in their dissatisfaction due to the gap between service cognitionbetween home stay operators and consumers or poor implementation [5]. How to improve and enhance service quality is one of the most important issues in business management for home stay operators. Therefore, based on the SERVQUAL scale, as proposed by Parasuraman, Zeithaml, and Berry [6-8], this research conducts field surveys and interviews home stay operators to formulate the service items that accord with the status of the home stay industry. Through a consumer questionnaire survey, service quality is analyzed byt test and IPA $[9,10]$, and the research results can be used by home stay operators as reference for managerialimprovements, market positioning, and marketing strategy adjustments.

\section{LITERATURE REVIEW}

\subsection{Home Stay}

Before December 2001, home stays had gained a certain development in many Taiwanese locations; however, good and poor quality weremixed. In order to rectify the chaos and solve the growing demands for tourist accommodations, Taiwan's government issued "Regulations for the Management of Home Stay Facilities" [11] in December 12, 2001, which stipulates that home 
stays in Taiwan canutilizepersonalunoccupied rooms to provide accommodation for tourists, and established areas are limited only to the following 9 types:

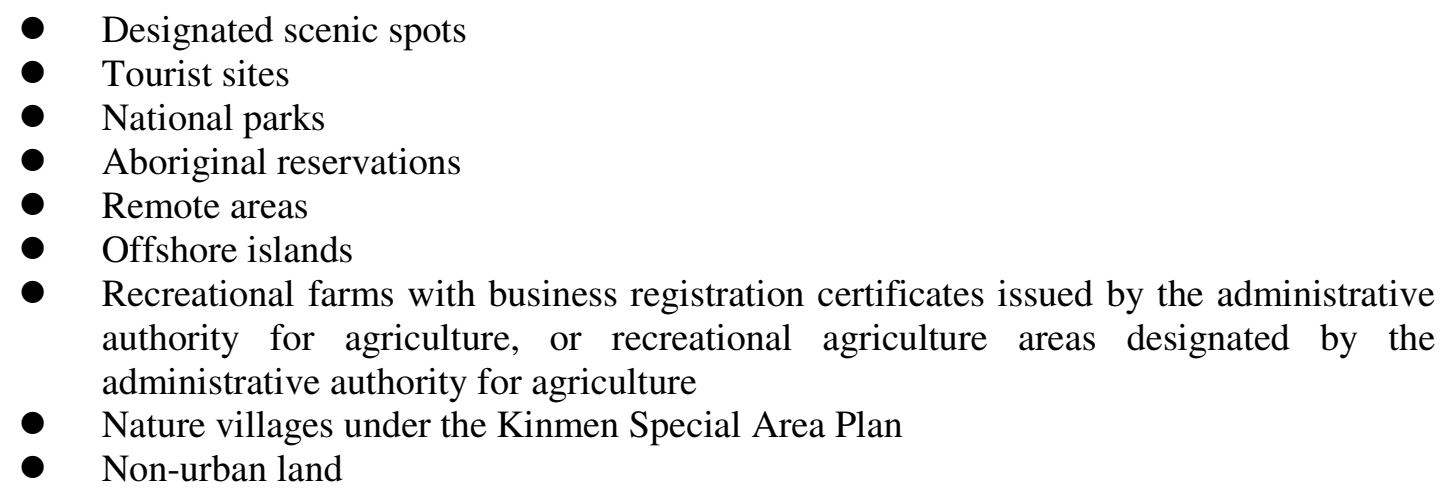

The number of rooms used for home stay cannot be excessive, and a maximum of 5 rooms is allowed formost home stays; they should provide rural life experience to people by combining local cultural,natural landscapes, and ecological and environmental resources, as well as agriculture, forestry, fishery, and animal husbandry production activities.

\subsection{Important-Performance Analysis}

IPA is a measurement method based on importance and performance, and is a technology to sort service items $[9,10]$, thus, it is an effective technology for improving service quality. This research uses IPA to conduct analysis, and the steps are shown, as follows [12]:

Step 1. List the service items, and develop them into a questionnaire.

Step 2. Invite consumers to rate various services according to "Importance" and "Performance".

Step 3. Take "Importance" as the horizontal axis and "Performance" as the vertical axis, and mark the service items in the two-dimensional space.

Step 4. Divide the space into 4 Quadrants (Figure 1) with the average as the separation point.

Regarding the relevant indices [9,10,12-16], and according to IPA analysis, if the service item belongs to Quadrant I (Keep Up the Good Work), it means that consumers' expectation and satisfaction for this service is high, and the operator of this service item should $\left\ulcorner_{\text {keep }}\right.$ up the good work $\lrcorner$ in future management; if the service item belongs to Quadrant II (Possible Overkill), it means that consumers' expectation for this service is low but their satisfaction is high. This service item can meet the demands of consumers, but $\ulcorner$ over-supplied $\lrcorner$, the operator should make adjustments according to the situation in future management; if the service item belongs to Quadrant III (Low Priority), it means that consumers' expectation and satisfaction for this service is low, and operators may give $\Gamma_{\text {low }}$ priority $\lrcorner$ to this service item during management improvement; If the service item belongs to Quadrant IV (Concentrate Here), it means that the consumers' expectation for this service is high, but satisfaction is low, and operatorsshould $\ulcorner$ strengthen the improvement of $\lrcorner$ this service item immediately; 


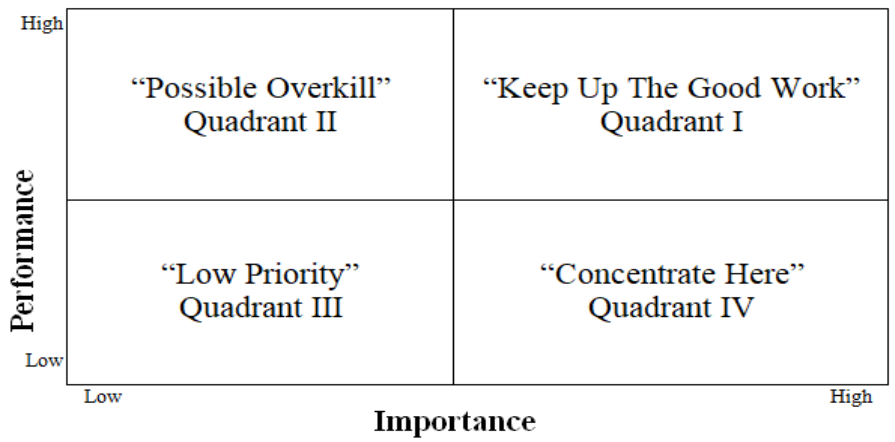

Figure 1. Importance-Performance Analysis

\section{RESEARCH METHOD}

This research formulates a questionnaire, and adopts a questionnaire survey by literature review, field survey, and interviews with home stay operators to measure the service quality of home stays. With consumers in Yilan County as the subjects, 400 questionnaires are distributed, and 321 valid questionnaires are retrieved.

\subsection{Paired-Samples t Test}

Paired-samples $\mathrm{t}$ testis applied to analyze whether there are significant differences between consumers' expectations of services prior to the home stay and satisfaction after experiencing the home stay, and the verification results are shown in Table 2. Table 2shows that there are significant differences in the remaining 17 questions, with the exception of items No. 3, 6, 15, 17, and 19; moreover, there are some cases where satisfaction is higher than the expectation, which shows that the performance of the service items provided by the home stay operators is generally beyond the expectation of the consumer.

Table 2. Results of Paired-Samples T Test

\begin{tabular}{|c|c|c|c|c|c|c|}
\hline & Variable & $\begin{array}{l}\text { Average of } \\
\text { the } \\
\text { Expectation } \\
\text { (I) }\end{array}$ & $\begin{array}{l}\text { Average of } \\
\text { the } \\
\text { Satisfaction } \\
\text { (S) }\end{array}$ & S-I & P Value & $P<0.05$ \\
\hline \multirow{7}{*}{$\begin{array}{l}\text { Facilities and } \\
\text { Equipment }\end{array}$} & 1. Parking spaces & 3.58 & 3.97 & 0.39 & 0.000 & $\mathrm{~V}$ \\
\hline & 2. Social hall & 3.68 & 4.25 & 0.57 & 0.000 & $\mathrm{~V}$ \\
\hline & $\begin{array}{l}\text { 3. Sanitary bathroom } \\
\text { equipment }\end{array}$ & 3.38 & 3.69 & 0.31 & 0.066 & \\
\hline & 4. Supply of spare products & 3.29 & 3.61 & 0.32 & 0.037 & $\mathrm{~V}$ \\
\hline & 5. Entertainment devices & 3.61 & 4.13 & 0.52 & 0.000 & $\mathrm{~V}$ \\
\hline & $\begin{array}{l}\text { 6. Kitchen, barbecue, and other } \\
\text { cooking equipment }\end{array}$ & 3.38 & 3.69 & 0.31 & 0.066 & \\
\hline & 7. Simple medical devices & 3.29 & 3.61 & 0.32 & 0.037 & V \\
\hline
\end{tabular}


International Journal of Computer Science \& Information Technology (IJCSIT) Vol 11, No 4, August 2019

\begin{tabular}{|c|c|c|c|c|c|c|}
\hline \multicolumn{2}{|c|}{ Variable } & $\begin{array}{l}\begin{array}{c}\text { Average of } \\
\text { the } \\
\text { Expectation } \\
\text { (I) }\end{array} \\
\end{array}$ & \begin{tabular}{|c|}
$\begin{array}{c}\text { Average of } \\
\text { the } \\
\text { Satisfaction } \\
\text { (S) }\end{array}$ \\
\end{tabular} & S-I & $P$ Value & $\mathrm{P}<0.05$ \\
\hline & 8. Supply of network devices & 3.61 & 4.13 & 0.52 & 0.000 & $\mathrm{~V}$ \\
\hline & 9. Fire safety devices & 3.85 & 4.25 & 0.40 & 0.000 & $\mathrm{~V}$ \\
\hline \multirow{5}{*}{$\begin{array}{l}\text { Recreation } \\
\text { Service }\end{array}$} & 10. Supply of catering & 3.40 & 3.81 & 0.41 & 0.000 & $\mathrm{~V}$ \\
\hline & $\begin{array}{l}\text { 11. Arrangements for } \\
\text { neighboring sightseeing and } \\
\text { recreational resources }\end{array}$ & 3.58 & 4.12 & 0.54 & 0.000 & $\mathrm{~V}$ \\
\hline & $\begin{array}{l}\text { 12. Service of ordering local } \\
\text { agricultural products on } \\
\text { behalf of the tourist }\end{array}$ & 3.53 & 3.93 & 0.40 & 0.000 & $\mathrm{~V}$ \\
\hline & $\begin{array}{l}\text { 13. On-site explanations of } \\
\text { environmental resource } \\
\text { characteristics by specially- } \\
\text { assigned person }\end{array}$ & 3.51 & 3.83 & 0.33 & 0.024 & $\mathrm{~V}$ \\
\hline & $\begin{array}{l}\text { 14. Supply of transportation } \\
\text { services }\end{array}$ & 3.27 & 3.82 & 0.54 & 0.000 & $\mathrm{~V}$ \\
\hline \multirow{3}{*}{$\begin{array}{l}\text { Environmental } \\
\text { Scene }\end{array}$} & $\begin{array}{l}\text { 15. Interior decoration and the } \\
\text { application of overall space }\end{array}$ & 3.31 & 3.61 & 0.30 & 0.092 & \\
\hline & $\begin{array}{l}\text { 16. Outdoor greening of the } \\
\text { surrounding environment } \\
\text { and view }\end{array}$ & 3.40 & 3.80 & 0.40 & 0.000 & $\mathrm{~V}$ \\
\hline & 17. Architectural appearance & 3.20 & 3.43 & 0.23 & 0.158 & \\
\hline \multirow{5}{*}{$\begin{array}{l}\text { Operating } \\
\text { Management }\end{array}$} & 18. Advertisement & 3.42 & 3.88 & 0.42 & 0.000 & $\mathrm{~V}$ \\
\hline & $\begin{array}{l}\text { 19. Arrangement of location } \\
\text { indicator of the home stay }\end{array}$ & 3.19 & 3.44 & 0.25 & 0.096 & \\
\hline & 20. Price & 3.35 & 3.66 & 0.32 & 0.034 & $\mathrm{~V}$ \\
\hline & 21. Speed of complaint handling & 3.60 & 4.11 & 0.51 & 0.000 & $\mathrm{~V}$ \\
\hline & 22. Qualified service personnel & 3.53 & 3.96 & 0.43 & 0.000 & $\mathrm{~V}$ \\
\hline
\end{tabular}

\subsection{IPA}

The IPA analysis results are shown in Figure 2 and Table 3. In terms of belonging to a Quadrant in IPA, a total of 9 items belong to Quadrant I (Keep up the Good Work), 1 item belongs to Quadrant II (Possible Overkill), 11 items belong to Quadrant III (Low Priority), and 1 item belongs to Quadrant IV (Concentrate Here). 


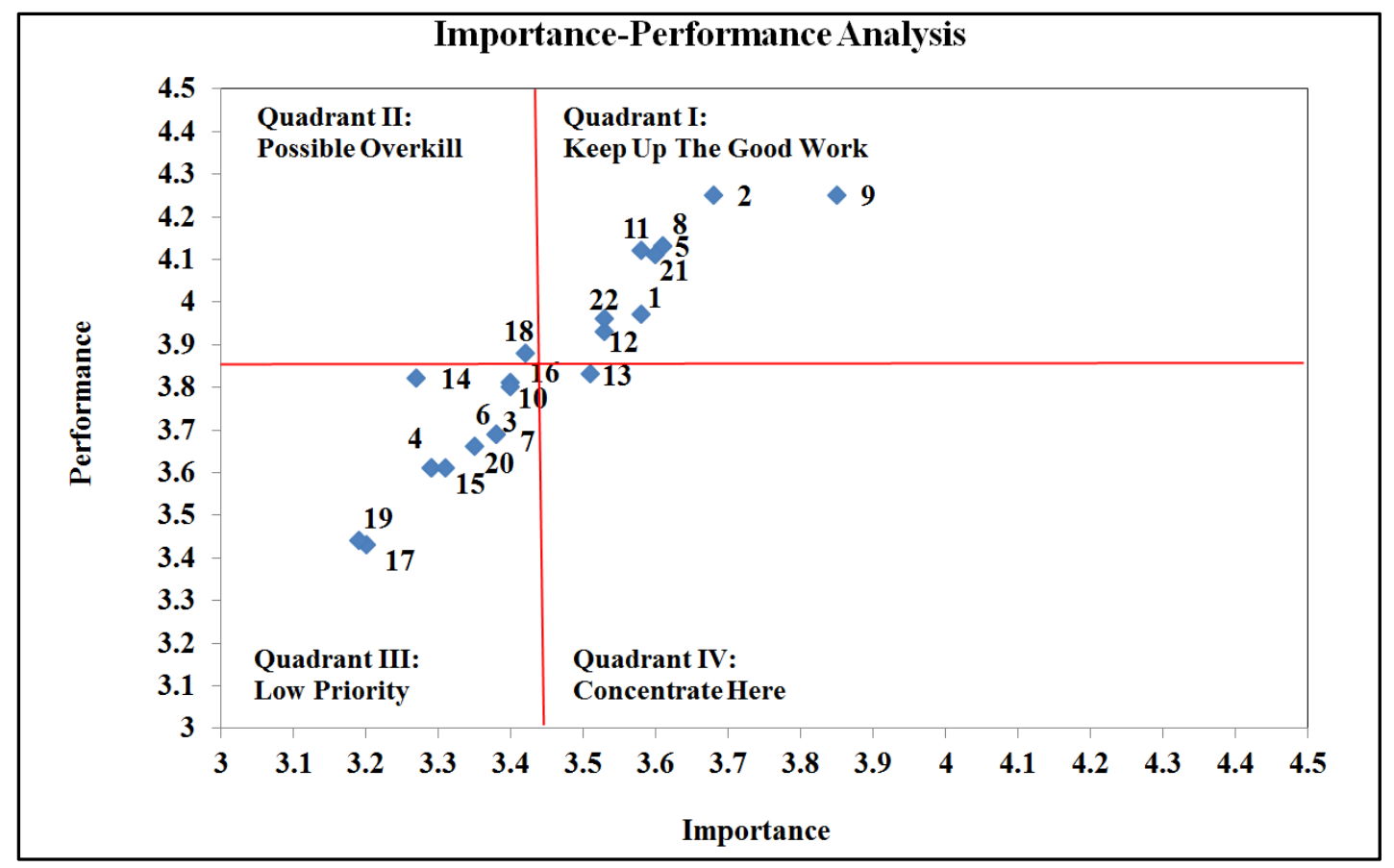

Figure 2. IPA results (means as center)

Table 3. The designation of questions in the IPA Quadrants

\begin{tabular}{|c|l|}
\hline Quadrant & Item number \\
\hline $\begin{array}{c}\text { Quadrant I: } \\
\text { Keep Up The Good Work }\end{array}$ & $1,2,5,8,9,11,12,21,22$ \\
\hline $\begin{array}{c}\text { Quadrant II: } \\
\text { Possible Overkill }\end{array}$ & 18 \\
\hline $\begin{array}{c}\text { Quadrant III: } \\
\text { Low Priority }\end{array}$ & $3,4,6,7,10,14,15,16,17,19,20$ \\
\hline $\begin{array}{c}\text { Quadrant IV: } \\
\text { Concentrate Here }\end{array}$ & 13 \\
\hline
\end{tabular}

\section{ConClusion}

Based on the SERVQUAL questionnaire, this research adopts field survey, interviews with home stay operators, consumer survey, paired-samples t test, IPA, etc. to analyze the service performances of home stays, and the research results show that only a few service items fail to exceed the expectations of consumers. If home stay operators want to improve their operational performance, they should first improve the service items in "Quadrant IV: Concentrate Here" in the short run, in order to improve consumer satisfaction. Regarding improvementsto mediumterm and long-term operational performance, they should focus on the service items in "Quadrant I: Keep Up the Good Work" for external marketing to enhance competitiveness. The supply of the service items in "Quadrant II: Possible Overkill" can be decreased to reduce costs and resource expenditures. The service items in "Quadrant III: Low Priority" do notrequire immediate improvement, and can be improved slowly. 
International Journal of Computer Science \& Information Technology (IJCSIT) Vol 11, No 4, August 2019

\section{REFERENCES}

[1] Tourism Burean, M.O.T.C. Republic of China (Taiwan), (2018) "2017 survey of travel by R.O.C citizens executive summary", http://admin.taiwan.net.tw/statistic/, Accessed 1 May. 2019.

[2] H. C. Huang, H. W. Wang, (2012)“Green Marketing and Accommodation Intention: Take Rural B\&Bs as an Example", Journal of Soil and Water Conservation Technology, Vol. 6, No. 4, pp. 1523.

[3] J. R. Lin, T. F. Kuo,(2011) "Operation Efficiency of the B\&B Industry in Taiwan's Sun-Moon Lake Scenic Area: First Evidence”, Service Industry Management Review, Vol. 9, No. 1, pp. 87-103.

[4] Tourism Burean, M.O.T.C. Republic of China (Taiwan), (2019) "March 2019 Monthly Report on Home Stay Facilities Operations in Taiwan", http://admin.taiwan.net.tw/statistic/, Accessed 1 June 2019.

[5] Y. C. Lin,(2010) "A Study of Home-Stay Demand Differences among Various Home-Stay Consumption Segments",Journal of Sport and Recreation Research, Vol. 4, No. 3, pp. 85-105.

[6] V. A. Zeithaml, L. L. Berry and A. Parasuraman, (1988) "CommuniCation and Control Processes in the Delivery of Service Quality”, Journal of Marketing, Vol. 52, No.2, pp. 35-48.

[7] A. Parasuraman, L. L. Berry and V. A. Zeithaml, (1991) "Refinement and Reassessment of the SERVQUAL Scale“, Journal of Retailing, Vol. 67, No. 4, pp. 420-450.

[8] A. Parasuraman, V.A. Zeithaml, and L.L. Berry, (1994) "Reassessment of Expectations as a Comparison Standard in Measuring Service Quality : Implications for Further Research”, Journal of Marketing, Vol. 58, No. 1, pp. 111-124.

[9] J.A. Martilla and J.C. James, (1977) "Importance-Performance Analysis", Journal of Marketing, Vol. 41, No.1, pp.77-79, 1977.

[10] S.E Sampson and M.J. Showalter, (1999) "The Performance-Importance Response Function: Observations and Implications", The Service Industries Journal, Vol. 19, No. 1, pp, 1-25, 1999.

[11] Tourism Burean, M.O.T.C. Republic of China (Taiwan), (2012) "Regulations for the Management of Home Stay Facilities", http://admin.taiwan.net.tw/law/, Accessed 1 June 2012.

[12] W.J. Deng, Y. F. Kuo, W. C. Chen, (2008) "Revised Importance-Performance Analysis: ThreeFactor Theory and Benchmarking”, The Service Industries Journal, Vol. 28, No. 1, pp. 37-51.

[13] S.M. ELseuofi,(2012) "Quality of Service Using PSO Algorithm”, International Journal of Computer Science \& Information Technology, Vol. 4, No. 1, pp.165-175.

[14] M.A Mahfuz, L.Khanam and W. Hu,(2016)"Examine Website Quality on M-Banking Services Adoption in Bangladesh",International Journal of Computer Science \& Information Technology, Vol.8, No.2, pp. 33-50.

[15] M.A Islam, J.Ferdaus, M.A.A khan and M.T Habib, (2018) "Online Legal Service: The Present and Future", International Journal of Computer Science \& Information Technology, Vol. 10, No.5, pp.13-20.

[16] A.M Osman and N.I Osman, (2018) "A Comparison of Cache Replacement Algorithms for Video Services", International Journal of Computer Science \& Information Technology, Vol. 10, No.2, pp. 95-111. 